\title{
Physical and Chemical Components of Cuba's Rain: Effects on Air Quality
}

\author{
Margarita Préndez, ${ }^{1}$ Rosemary López, ${ }^{2}$ and Ernesto Carrillo ${ }^{2}$ \\ ${ }^{1}$ Laboratorio de Química de la Atmósfera, Facultad de Ciencias Químicas y Farmacéuticas, Universidad de Chile, \\ RM8380492 Santiago, Chile \\ ${ }^{2}$ Centro de Contaminación y Química Atmosférica, Instituto de Meteorología de Cuba, La Habana, Cuba
}

Correspondence should be addressed to Margarita Préndez; mprendez@ciq.uchile.cl

Received 30 April 2014; Accepted 8 July 2014; Published 12 August 2014

Academic Editor: Prodromos Zanis

Copyright (C) 2014 Margarita Préndez et al. This is an open access article distributed under the Creative Commons Attribution License, which permits unrestricted use, distribution, and reproduction in any medium, provided the original work is properly cited.

The objective of this study was to analyze the influence of the physical and chemical components of rain affecting air quality in Cuba. Samples were obtained from pollution monitoring stations throughout Cuba. Different chemical analyses including elements and ions were conducted. Meteorological data was also included for the analysis. Results show that the $\mathrm{pH}$ was slightly basic for most stations, except those of the eastern region which exhibit $\mathrm{pH}$ values below 5.6. The major anthropogenic sources of ions are the burning of fossil fuel by power plants, cement factories, and nickel-processing industries and the burning of biomass through poor agricultural practices. The western region exhibited increased concentrations of $\mathrm{NO}_{3}{ }^{-}$and $\mathrm{SO}_{4}{ }^{2-}$ during the dry season, most likely due to the long-range transport of pollutants from the northeastern United States as well as local pollutants. Marine aerosols clearly influence Cuba's rain. Only a small fraction of the potentially acidic ions contributes to the free acidity of Cuba's rainwater, mainly due to the neutralizing capacity of some ions such as $\mathrm{Cl}^{-}, \mathrm{Na}^{+}, \mathrm{Ca}^{+2}$, and $\mathrm{NH}_{4}^{+}$. The implementation of abatement techniques for $\mathrm{SO}_{2}$ and NOX and some elements emissions from major stationary sources will be an effective measure to improve air quality in Cuba.

\section{Introduction}

The fall of rain, snow, fog, and dew is the mechanism that permanently removes gases and particles from the atmosphere [1], an important role, especially in countries with a humid climate. The acidity and the concentration of ions in rainwater depend on the type and magnitude of its sources, its physical incorporation into the water system, and the chemical transformation during the formation of clouds and drag below them [2].

Acid rain is any form of wet precipitation of $\mathrm{pH}<5.6$ [2]. Acid rain is a major environmental problem, especially across national boundaries in the Northern Hemisphere due to the movement of air masses over long distances [2]. In recent years such movement has spread to other parts of the world, especially Asia and tropical countries, becoming a problem for the tropics due to its abundant precipitation [3]. Acid rain reduces growth in trees and increases their vulnerability to pathogens and pests and causes leaching of nutrients, acidification of soils, and modification to the ecology of lakes. Acid rain also causes the dissolution of $\mathrm{CaCO}_{3}$ in the monuments and buildings of limestone or marble [4].

Rainwater contains elements in the range of $\mu \mathrm{g} / \mathrm{L}$, some of which dissolve at acid $\mathrm{pH}$, affecting human health and the ecosystem. The presence of those elements in the atmosphere is mainly due to various anthropogenic activities [5].

During the period 1981-1994, an increasing trend in the frequency of acid rain nationwide was observed in Cuba; this trend has possibly intensified in recent years due to the increased use of fuel oil with native sulfur content of $4-7 \%$.

The purpose of this study is to analyze the influence of the major physical and chemical components of rain on 

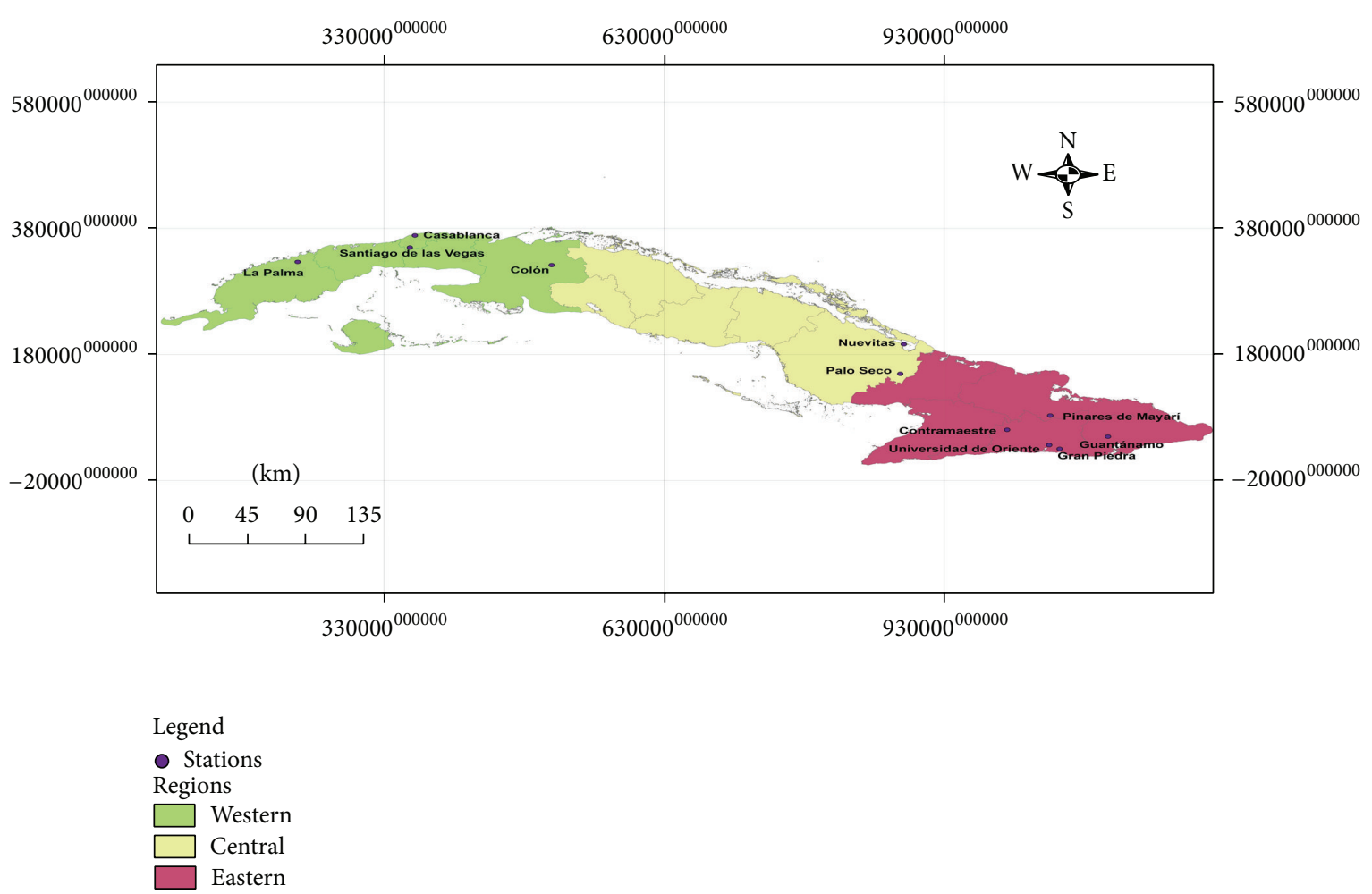

FIGURE 1: Location of the 11 air quality monitoring stations belonging to the Institute of Meteorology of Cuba.

Cuba that account for the origin of pollutants affecting its air quality.

\section{Materials and Methods}

Monthly samples collected by the stations of the Centro de Contaminación y Química de la Atmósfera (Pollution and Atmospheric Chemistry Center) of the Institute of Meteorology of Cuba were used. The period of sampling was November 2008 to April 2010. The sampling method recommended by the World Meteorological Office (WMO) for operating manuals rain and wet precipitation collectors was used [5-8]. Before each time it rains, collector was cleaned with deionized water and exposed only during the event. The samples were transferred to a polyethylene bottle. An aliquot of whole event collected during a month was transferred to a clean polyethylene bottle, creating a monthly "average" sample stored in a dark place cooled to $4^{\circ} \mathrm{C}$ for the chemical analyses. Figure 1 shows the location of the 11 monitoring stations.

A conductivity meter LF 539 WTD and a $\mathrm{pH}$ meter Oakton 1100 series were used. The $\mathrm{pH}$ meter was calibrated in the range 4-7 before every use. Ions $\mathrm{NH}_{4}{ }^{+}, \mathrm{Na}^{+}, \mathrm{K}^{+}, \mathrm{Mg}^{2+}$, $\mathrm{Ca}^{2+}, \mathrm{F}^{-}, \mathrm{NO}_{2}{ }^{-}, \mathrm{NO}_{3}{ }^{-}, \mathrm{SO}_{4}{ }^{2-}, \mathrm{Cl}^{-}, \mathrm{CH}_{3} \mathrm{COO}^{-}, \mathrm{HCOO}^{-}$, and $\mathrm{CH}_{3} \mathrm{SO}_{3}{ }^{-}$were quantified with a Dionex ion chromatograph model ICS 3000. Optical emission spectrometry along with inductively coupled plasma (ICP-OES) PE Optima XL 3300 was used for chemical element quantification. Certified standards for elements and ions were used. Detection and quantification limits were calculated as 3 and 10 times the standard deviation, respectively.

The volume-weighted mean concentrations (VWMC) for ions expressed in $\mu \mathrm{eq} / \mathrm{L}$ for the elements in $\mu \mathrm{g} / \mathrm{L}$ were calculated according to (1) [1]:

$$
\mathrm{VWMC}=\frac{\sum\left(C_{n} * P_{n}\right)}{\sum P_{\text {period }}},
$$

where $C_{n}$ is concentration of the analyte in the sample expressed as $\mu \mathrm{eq} / \mathrm{L}$ or $\mu \mathrm{g} / \mathrm{L}, P_{n}$ is mm of total rainfall collected for the sample, and $P_{\text {period }}$ is the sum of the $\mathrm{mm}$ for the sampling period.

Wet deposit flow (FD) expressed in $\mathrm{meq} / \mathrm{m}^{2} *$ year or $\mathrm{mg} / \mathrm{m}^{2} *$ year was calculated using the following [9]:

$$
\mathrm{FD}=C_{n} * P_{n}
$$

where $C_{n}$ is concentration of chemical species expressed in $\mathrm{meq} / \mathrm{L}$ or $\mathrm{mg} / \mathrm{L}$ and $P_{n}$ is $\mathrm{mm}$ of rainfall in the month or period $(\mathrm{mm})$.

Neutralization factors, NF, were calculated using the following [10]:

$$
\mathrm{NF}_{i^{+}}=\frac{i^{+}}{\left(\mathrm{NO}_{3}{ }^{-}+\mathrm{SO}_{4}{ }^{2-}\right)}
$$


where $i$ corresponds to the respective ions, $\mathrm{NH}_{4}{ }^{+}, \mathrm{Mg}^{2+}$, and $\mathrm{Ca}^{2+}$, as

$$
\begin{aligned}
& \mathrm{NF}_{\mathrm{NH}_{4}+}=\frac{\mathrm{NH}_{4}^{+}}{\left(\mathrm{NO}_{3}{ }^{-}+\mathrm{SO}_{4}{ }^{2-}\right)}, \\
& \mathrm{NF}_{\mathrm{Mg}^{2+}}=\frac{\mathrm{Mg}^{2+}}{\left(\mathrm{NO}_{3}{ }^{-}+\mathrm{SO}_{4}{ }^{2-}\right)}, \\
& \mathrm{NF}_{\mathrm{Ca}^{2+}}=\frac{\mathrm{Ca}^{2+}}{\left(\mathrm{NO}_{3}{ }^{-}+\mathrm{SO}_{4}{ }^{2-}\right)}
\end{aligned}
$$

Marine contribution to concentrations of ions was estimated according to the following [11]:

$$
[\mathrm{X}]_{\text {sea }}=\left[\mathrm{Na}^{+}\right]_{\text {rain }}\left(\frac{[\mathrm{X}]}{\left[\mathrm{Na}^{+}\right]}\right)_{\text {sea }},
$$

where $[\mathrm{X}]_{\text {sea }}$ is marine contribution to the X element in $\mu$ eq/L, $\left[\mathrm{Na}^{+}\right]_{\text {rain }}$ is concentration of $\mathrm{Na}^{+}$in the rain $(\mu$ eq/L), and $\left([\mathrm{X}] /\left[\mathrm{Na}^{+}\right]\right)_{\text {sea }}$ is the relative concentration of ions in seawater $(\mu$ eq/L).

Contribution to the ions from the terrestrial crust, biogenic and anthropogenic $\left(\mathrm{X}_{\mathrm{ns}}\right)$, called ion concentrations in excess, was calculated according to the following:

$$
[\mathrm{X}]_{\mathrm{ns}}=[\mathrm{X}]_{\mathrm{rain}}-[\mathrm{X}]_{\text {sea }} .
$$

The ratio between neutralization potential (NP) and acidification potential (AP) was calculated according to the following [5]:

$$
\frac{\mathrm{NP}}{\mathrm{AP}}=\frac{\left[\mathrm{NH}_{4}{ }^{+}+\left(\mathrm{Ca}^{2+}\right)_{\mathrm{ns}}\right]}{\left[\mathrm{NO}_{3}{ }^{-}+\left(\mathrm{SO}_{4}{ }^{2-}\right)_{\mathrm{ns}}\right]} .
$$

Enrichment factors (EF) for elements and ions were calculated according to the following [12]:

$$
\begin{gathered}
\mathrm{EF}=\frac{\left(\mathrm{X} / \mathrm{Na}^{+}\right)_{\text {rainwater }}}{\left(\mathrm{X} / \mathrm{Na}^{+}\right)_{\text {seawater }}} \\
\mathrm{EF}=\frac{(\mathrm{X} / \mathrm{Fe})_{\text {rainwater }}}{(\mathrm{X} / \mathrm{Fe})_{\text {terrestrial crust }}},
\end{gathered}
$$

where $\mathrm{X}$ is the concentration of the ion or element of interest.

The principal component analysis with orthogonal rotation was performed using SPSS version 17 for Windows XP.

The type of monthly predominantly synoptic situation (TSS) for western, central, and eastern Cuba was determined using the statistic of mode, and the information was collected regarding the number of cold fronts affecting each region. Two periods of rain can be distinguished in Cuba: the low volume rain periods, November-April that we are calling the "dry period," and May-October, the rainy period called "wet period."

\section{Results and Discussion}

Figure 2 shows acid rain in Pinares de Mayari, Gran Piedra, and Palo Seco, but not in the rest of the stations.
Pinares de Mayari and Gran Piedra stations (under the direct influence of the prevailing winds from the NE) show the impact of high sulfur emissions from the mining sector of Moa and the Felton thermoelectric plant burning fuel oil and native crude oil for power generation. In the western region, $\mathrm{pH}$ values in the dry season suggest the influence of seasonal weather conditions, such as the arrival of cold fronts, which have traveled from the NE US (with high industrialization) and transport high concentrations of $\mathrm{SO}_{4}{ }^{2-}$ and $\mathrm{NO}_{3}{ }^{-}[13$, 14].

Figure 3 shows that the concentrations of $\mathrm{SO}_{4}{ }^{2-}$ and $\mathrm{NO}_{3}{ }^{-}$are above the background values of $2.50 \mu \mathrm{eq} / \mathrm{L}$ and $10 \mu \mathrm{eq} / \mathrm{L}$, respectively, reported in the Northern Hemisphere [15]. The highest concentrations were quantified in Pinares de Mayari and Gran Piedra, probably due to the influence of mesoscale emissions of the thermoelectric plant located in the northern part of the eastern provinces.

In the western and central regions greater concentrations of non-sea sulfate, but not necessarily of nitrate, were determined during the dry period than in the wet period, and this may be associated with the movement of air masses of cold fronts from the US passing over Cuba and increasing the $\mathrm{SO}_{4}{ }^{2-}$ concentrations due to their transport of pollutants, in addition to industrial centers located NW of the Cuban stations. Improved results could be obtained in the future using individual events and back trajectories [17].

Figure 4 shows that the contribution to the total acidity in urban stations of mineral acids $\left(\mathrm{HNO}_{3}\right.$ and $\left.\mathrm{H}_{2} \mathrm{SO}_{4}\right)$ ranges between 80 and $90 \%$ with the contribution of the organic acid $\left(\mathrm{HCOOH}\right.$ and $\left.\mathrm{CH}_{3} \mathrm{COOH}\right)$ between 10 and $20 \%$. In rural stations the contribution of organic acid is 20 to $45 \%$ and the mineral acid 65 to $80 \%$. In Pinares de Mayari, a rural station, only $10 \%$ are organic acids and $90 \%$ mineral, suggesting again the direct influence of winds from the north east coast (industrial area).

Table 1 shows that the highest rates of deposit, FD, correspond to $\mathrm{Cl}^{-}$and $\mathrm{Na}^{+}$, reflecting the influence of marine aerosols on rainfall for the island. The $\mathrm{FD}$ of $\mathrm{NO}_{3}{ }^{-}, \mathrm{SO}_{4}{ }^{2-}$, $\mathrm{NH}_{4}{ }^{+}, \mathrm{Mg}^{2+}$, and $\mathrm{Ca}^{2+}$ in rural stations is much higher than in a rural station of NW Europe, suggesting the transport of chemical species from other sites. The high FD of formate in Guantanamo suggests the biomass burning in the sugar cane fields, an environmentally unwise practice [18]. Table 2 shows that the FD in urban stations has the highest values for $\mathrm{Cl}^{-}$, $\mathrm{Na}^{+}, \mathrm{Ca}^{2+}$, and $\mathrm{SO}_{4}{ }^{2-}$. The concentration of $\mathrm{SO}_{4}{ }^{2-}$ in Santiago de Las Vegas is as high as in the industrialized area of NE US. This suggests that Cuban fossil fuel burning contributes to increased emissions of $\mathrm{SO}_{2}$. However, the concentrations of $\mathrm{Ca}$ and $\mathrm{Mg}$ explain the neutralization of acidic species. The FD of formate and acetate quantified may be associated with natural emissions of urban trees [9].

Table 3 shows the prevalence of $\mathrm{Ca}^{2+}$ as the principal neutralizing ion of rain in Cuba, except in Colón where it also contributes $\mathrm{NH}_{4}^{+}$; this could be due to livestock activities developed in the vicinity of the station. The high values of $\mathrm{Ca}^{2+}$ are also linked to the resuspension of natural soil particles, rich in limestone (calcium carbonate) due to anthropogenic activities. Note that a correlation of $95 \%$ 


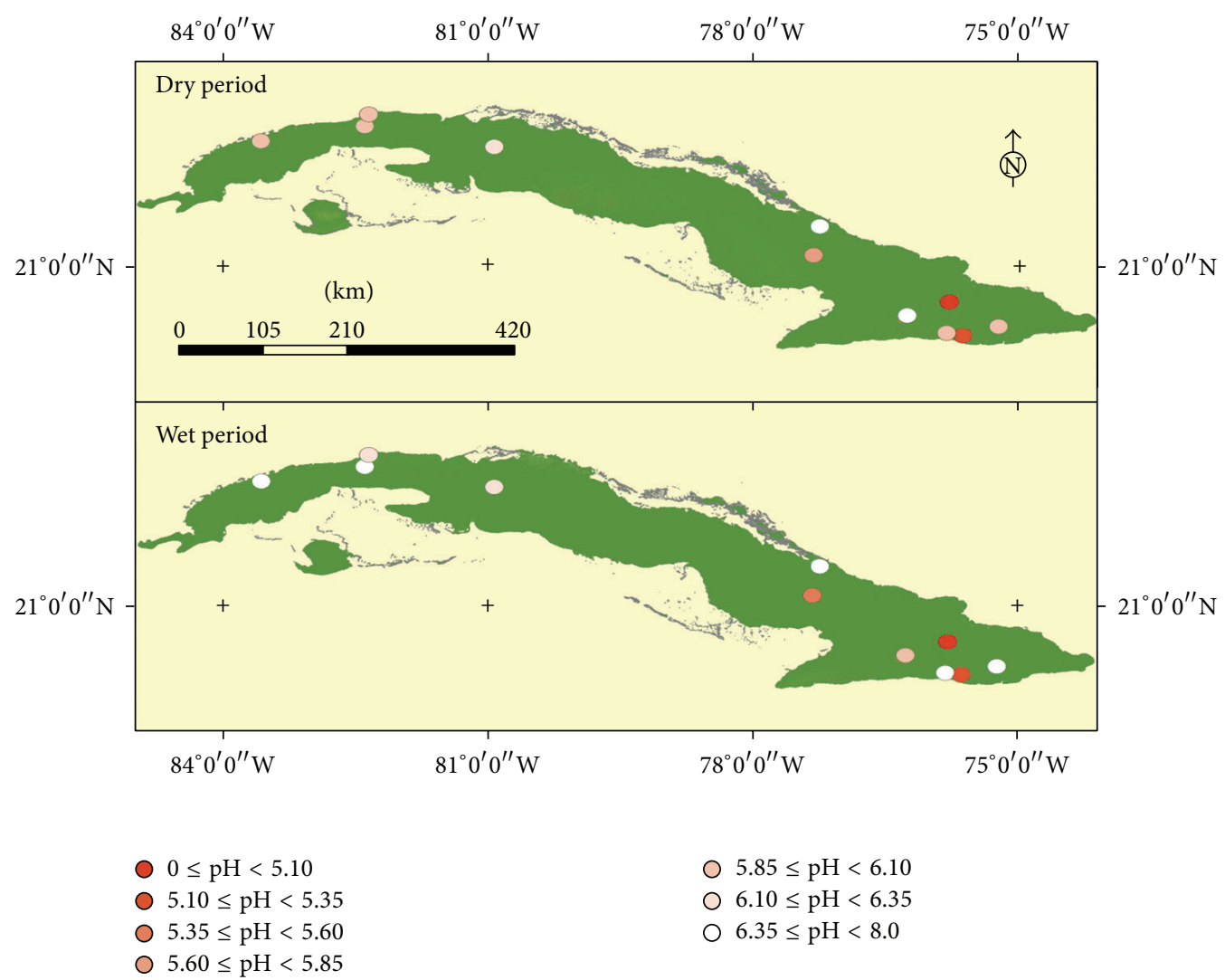

FIGURE 2: Weighted average pH values for the low-volume rain periods (November 2008-April 2009 and November 2009-April 2010) and the rainy period (May 2009-October 2009) in the 11 air quality monitoring stations of Cuba.

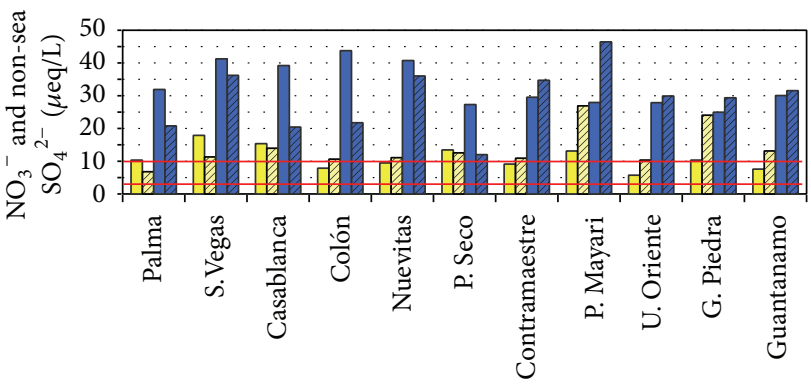

Stations

ㅁ Nitrate dry period

v Nitrate wet period
- Non-sea sulfate dry period

v Non-sea sulfate wet period

Figure 3: Volume weighted average concentrations of $\mathrm{NO}_{3}{ }^{-}$and non-sea $\mathrm{SO}_{4}{ }^{2-}$ in the rain for dry periods (November 2008-April 2009 and November 2009-April 2010) and rainy period (May 2009October 2009) in the 11 air quality monitoring stations of Cuba.

exists between ions $\mathrm{Ca}$ and $\mathrm{Mg}$ [19]. Similar influence of limestone has been recently obtained by Hong-wei et al. [20] in Guiyang, SW China. Other anthropogenic sources of $\mathrm{Ca}^{2+}$ are the cement factories in La Habana and Nuevitas, A similar effect produced by cement factories was reported in the southern region of Jordan in 2013 [21]. The lower

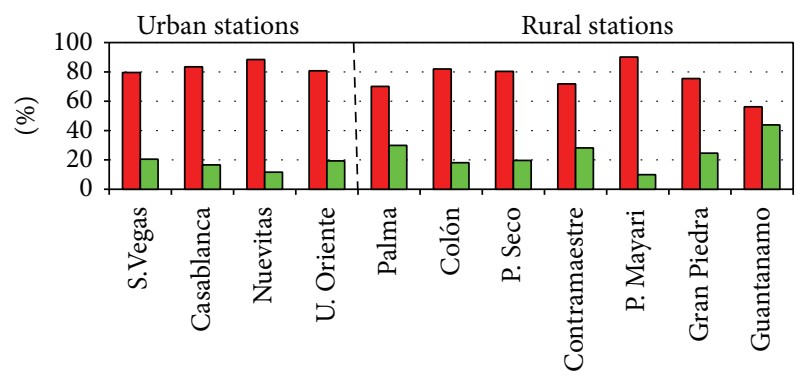

Stations

- Mineral acids

口 Organic acids

Figure 4: Contribution of mineral and organic acids to the total acidity in the rain over the 11 air quality monitoring stations of Cuba.

neutralization factors were found in Pinares de Mayari and Gran Piedra, which explains the acidity of rainfall of these stations.

Table 4 shows that the majority of the ratio NP/AP was $>1$, suggesting that, in rainfall at different localities in Cuba, there is a predominance of alkali species over the acid, except stations in Pinares de Mayari and Gran Piedra, consistent with their more acidic $\mathrm{pH}$ values. 
TABLE 1: Wet deposition flow (FD) for ions (meq $/ \mathrm{m}^{2} /$ year) monitoring air pollution urban stations in Cuba in the period of November 2008October 2009 and other urban places in the world.

\begin{tabular}{|c|c|c|c|c|c|c|c|c|}
\hline \multicolumn{9}{|c|}{ Wet deposition flow, meq $/ \mathrm{m}^{2} /$ year } \\
\hline & Palma & Colón & Palo Seco & C. Maestre & P. Mayari & G. Piedra & Guantanamo & NW Europe* \\
\hline $\mathrm{Cl}^{-}$ & 63.7 & 87.8 & 44.0 & 67.6 & 32.8 & 37.0 & 59.1 & - \\
\hline $\mathrm{NO}_{3}{ }^{-}$ & 9.0 & 14.0 & 11.4 & 10.3 & 22.5 & 20.6 & 11.9 & 5.0 \\
\hline $\mathrm{SO}_{4}^{2-}$ & 40.2 & 32.3 & 24.5 & 37.9 & 44.4 & 32.4 & 37.3 & 15 \\
\hline $\mathrm{CH}_{3} \mathrm{COO}^{-}$ & 4.2 & 3.5 & 4.7 & 6.2 & 3.1 & 8.1 & 11.9 & - \\
\hline $\mathrm{HCOO}^{-}$ & 11.4 & 4.4 & 3.1 & 10.8 & 3.8 & 7.8 & 37.3 & - \\
\hline $\mathrm{Na}^{+}$ & 55.2 & 46.7 & 41.2 & 41.3 & 32.1 & 34.5 & 50.7 & - \\
\hline $\mathrm{NH}_{4}^{+}$ & 16.0 & 47.5 & 12.5 & 21.1 & 11.4 & 9.1 & 18.1 & 5.0 \\
\hline $\mathrm{K}^{+}$ & 2.1 & 15.2 & 4.2 & 8.3 & 2.6 & 2.6 & 11.3 & - \\
\hline $\mathrm{Mg}^{2+}$ & 19.6 & 20.1 & 13.1 & 15.0 & 15.4 & 10.5 & 20.7 & 2.0 \\
\hline $\mathrm{Ca}^{2+}$ & 74.1 & 37.8 & 29.5 & 54.2 & 32.1 & 28.9 & 67.4 & 5.0 \\
\hline
\end{tabular}

${ }^{*}$ Migliavacca et al. [8]; - not informed.

TABLE 2: Wet deposition flow (FD) for ions ( $\mathrm{meq} / \mathrm{m}^{2} / \mathrm{year}$ ) in monitoring air pollution rural stations in Cuba during the period of November 2008-October 2009 and other rural sites in the world.

\begin{tabular}{|c|c|c|c|c|c|c|}
\hline \multicolumn{7}{|c|}{ Wet deposition flow, meq $/ \mathrm{m}^{2} /$ year } \\
\hline Ion & S. Vegas & Casablanca & Nuevitas & U. Oriente & NE of USA ${ }^{a}$ & Piracicaba Brasil ${ }^{\mathrm{b}}$ \\
\hline $\mathrm{Cl}^{-}$ & 93.9 & 35.2 & 108 & 74.3 & 25.0 & 7.4 \\
\hline $\mathrm{NO}_{3}^{-}$ & 16.9 & 8.5 & 7.8 & 8.4 & 30.0 & 18.4 \\
\hline $\mathrm{SO}_{4}{ }^{2-}$ & 56.0 & 15.1 & 32.2 & 35.6 & 65.0 & 20.0 \\
\hline $\mathrm{CH}_{3} \mathrm{COO}^{-}$ & 6.6 & 2.5 & 3.0 & 5.2 & - & - \\
\hline $\mathrm{HCOO}^{-}$ & 6.1 & 4.8 & 1.3 & 3.6 & - & - \\
\hline $\mathrm{Na}^{+}$ & 72.2 & 22.1 & 57 & 58.7 & 20.0 & 3.5 \\
\hline $\mathrm{NH}_{4}^{+}$ & 15.7 & 7.7 & 7.9 & 22.1 & 15.0 & 16.5 \\
\hline $\mathrm{K}^{+}$ & 8.2 & 1.2 & 7.2 & 12.3 & 2.0 & 4.2 \\
\hline $\mathrm{Mg}^{2+}$ & 41.5 & 6.4 & 20.4 & 10.2 & 5.0 & 2.0 \\
\hline $\mathrm{Ca}^{2+}$ & 103 & 28.5 & 85.7 & 42.1 & 15.0 & 5.8 \\
\hline
\end{tabular}

${ }^{\mathrm{a}}$ Migliavacca et al. [8]; ${ }^{\mathrm{b}}$ Lara et al. [16]; — not informed.

TABLE 3: Mean values of the neutralization factors for $\mathrm{Ca}^{2+}, \mathrm{NH}_{4}^{+}$, and $\mathrm{Mg}^{2+}$ in rainwater collected at monitoring air pollution stations in Cuba.

\begin{tabular}{lccc}
\hline Monitoring station & $\mathrm{NF} \mathrm{Ca}^{2+}(\mu \mathrm{eq} / \mathrm{L})$ & $\mathrm{NF} \mathrm{NH}_{4}^{+}(\mu \mathrm{eq} / \mathrm{L})$ & $\mathrm{NF} \mathrm{Mg}{ }^{2+}(\mu \mathrm{eq} / \mathrm{L})$ \\
\hline La Palma & 1.3 & 0.3 & 0.3 \\
Santiago de las Vegas & 1.3 & 0.2 & 0.5 \\
Casablanca & 1.3 & 0.3 & 0.2 \\
Colón & 0.8 & 0.8 & 0.4 \\
Nuevitas & 2.0 & 0.2 & 0.7 \\
Palo Seco & $\mathbf{0 . 8}$ & $\mathbf{0 . 3}$ & 0.3 \\
Contramaestre & 1.1 & 0.4 & 0.3 \\
Pinares de Mayari & $\mathbf{0 . 5}$ & $\mathbf{0 . 2}$ & 0.3 \\
Universidad de Oriente & $\mathbf{1 . 0}$ & $\mathbf{0 . 5}$ & 0.3 \\
Gran Piedra & 0.6 & 0.2 & 0.2 \\
Guantánamo & 1.4 & 0.4 & 0.4 \\
\hline
\end{tabular}

Table 5 shows that the enrichment factors (EF) for $\mathrm{Cu}$, $\mathrm{Mn}, \mathrm{Ba}, \mathrm{Co}$, and $\mathrm{Ni}$ were below 7 , suggesting predominant crustal origin; EF between 1 and 6 were considered indicative of natural origin by differences in their concentrations in the earth's crust for different parts of the world [12]. Zinc, Se, and $\mathrm{Pb}$ have an anthropogenic origin.

The principal component analysis for major ions at all stations showed a component that groups mainly $\mathrm{NO}_{3}{ }^{-}$ and $\mathrm{SO}_{4}{ }^{2-}$, which agrees with the anthropogenic sources of fossil fuels. The other component group, the $\mathrm{Cl}^{-}$and $\mathrm{Na}^{+}$, represents marine influence. In the stations Contramaestre and Guantanamo the third component grouping $\mathrm{CH}_{3} \mathrm{COO}^{-}$ and $\mathrm{K}^{+}$can be associated with biomass burning, probably related to the burning of the foliage of sugarcane for easier manual cutting and also burning of crop residues to finish off the sugar harvest (Table 6). In Contramaestre it was also 
TABLE 4: Mean values of $\mathrm{pH}$ and relationship neutralization potential/acidification potential in rainwater collected at monitoring stations of air pollution in Cuba during the period of November 2008-October 2009.

\begin{tabular}{lcc}
\hline Station & $\mathrm{pH}$ & $\mathrm{NP} / \mathrm{AP}^{*}$ \\
\hline La Palma & 6.06 & 1.7 \\
Santiago de las Vegas & 6.08 & 1.8 \\
Casablanca & 6.02 & 1.7 \\
Colón & 6.08 & 1.8 \\
Nuevitas & 6.44 & 2.6 \\
Palo Seco & $\mathbf{5 . 4 2}$ & $\mathbf{1 . 1}$ \\
Contramaestre & 6.04 & 1.7 \\
Pinares de Mayari & $\mathbf{4 . 7 3}$ & $\mathbf{0 . 7}$ \\
Universidad de Oriente & 6.02 & 1.7 \\
Gran Piedra & $\mathbf{5 . 1 9}$ & $\mathbf{0 . 8}$ \\
Guantánamo & 6.27 & 2.0 \\
\hline
\end{tabular}

*NP: neutralization potential; AP: acidification potential.

observed that $\mathrm{Ca}^{2+}$ grouped with $\mathrm{CH}_{3} \mathrm{COO}^{-}$and $\mathrm{K}^{+}$, which could be attributed to the resuspension of soil particles by the increase of heavy vehicles in the fields as well as the use of trucks on unpaved roads during the cutting of sugar cane [18].

Table 7 shows the prevalence of polar continental anticyclone the dry period, characterized by high polar influence on Cuban territory that introduces lower temperatures and northerly winds from the American continent. In the wet period, the North Atlantic anticyclone predominates and is characterized by humid winds coming from the east. Air masses coming from the mainland (west) bring concentrations of $\mathrm{NO}_{3}{ }^{-}$and $\mathrm{SO}_{4}{ }^{2-}$ much higher than those from the North Atlantic (east) [22]. It is noted also that the west was affected by a greater number of cold fronts (Table 7), in which clouds produce rain associated with their trajectory through an important part of the industrialized NE area of the US, increasing the transport of contaminants to the Caribbean, mainly during the dry period $[15,23]$.

Figures 5 and 6 confirm this hypothesis since the western and central regions reach higher concentrations during the dry period than during the wet period; in the eastern region the contrary situation was observed. Also, cold fronts can carry pollutants from urban and industrial sites located in western Cuba, increasing concentrations of $\mathrm{NO}_{3}{ }^{-}$and nonsea $\mathrm{SO}_{4}{ }^{2-}$ in the eastern and western regions. In the eastern region stations highest concentrations were observed during the wet period possibly associated with the predominance of the North Atlantic anticyclone, characterized by the predominance of the $\mathrm{NE}$ winds component that facilitates the transport of $\mathrm{NO}_{3}{ }^{-}$and non-sea $\mathrm{SO}_{4}{ }^{2-}$ from a thermoelectric plant and the industrial zone for nickel processing to the monitoring stations in the eastern provinces.

\section{Conclusions}

The high levels of acid deposit, mainly of sulfates in different locations similar to those that have appeared in adverse environmental impacts in areas of North America, suggest

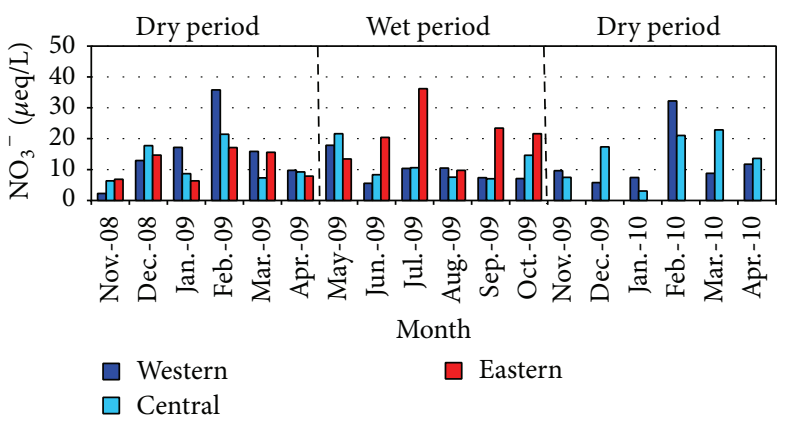

FIGURE 5: Monthly variation of $\mathrm{NO}_{3}{ }^{-}$concentrations in rain during the period of November 2008-April 2010 at the monitoring stations grouped in the western region, central region, and eastern region.

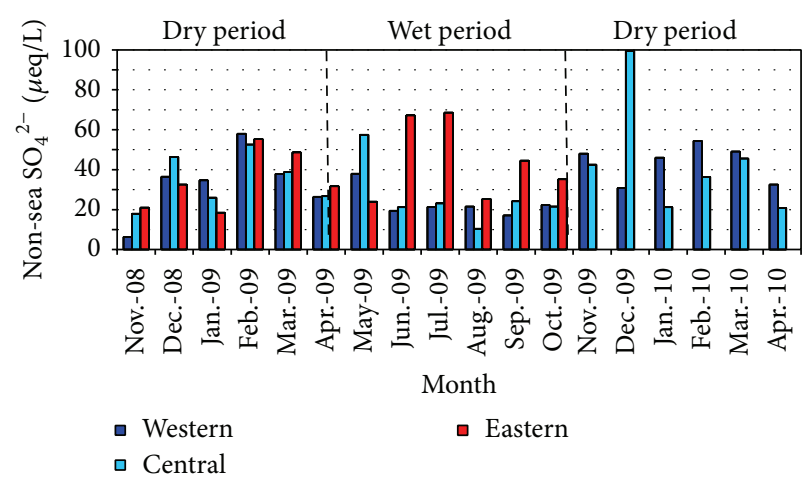

FIGURE 6: Monthly variation of non-sea $\mathrm{SO}_{4}{ }^{2-}$ concentrations in rain during the period of November 2008-April 2010 at the monitoring stations grouped in the western region, central region, and eastern region.

that anthropogenic emissions of $\mathrm{SO}_{2}$, through the use of fossil fuel with $4-7 \%$ sulfur content, constitute the main problem for Cuba air quality.

The anthropogenic origin of the elements nickel, zinc, selenium, and lead, which generate risks to human health and ecosystems, shows the need to control and develop environmentally sound production processes.

In most parts of the country, calcium concentrations contribute to neutralize the acidity of rainfall, thus avoiding most problems with acid rain. The free acidity of rainfall is only evident in areas where the influence of emissions of precursor gases is higher due to local sources and there are lower concentrations of neutralizing compounds, such as the stations in Pinares de Mayari, Gran Piedra, and Palo Seco. In this sense an isotopic analysis of $\mathrm{H}$ and $\mathrm{O}$ in rain could be very useful for better estimating the origin of $\mathrm{Ca}^{+2}[19]$.

At the national level, the most probable anthropogenic sources are the burning of fossil fuels in power plants, the nickel industry, the cement factories, and the burning of biomass in cane fields. It is therefore important to stress the need to control and monitor efficiently and effectively these activities. 
TABLE 5: Enrichment factors of the elements present in rainwater collected in Cuba in the period of November 2008-October 2009.

\begin{tabular}{lccccccc}
\hline & \multicolumn{9}{c}{ Enrichment factors* } & & \\
Station & $\mathrm{Zn}$ & $\mathrm{Cu}$ & $\mathrm{Mn}$ & $\mathrm{Ba}$ & $\mathrm{Se}$ & $\mathrm{Co}$ & $\mathrm{Ni}$ \\
\hline Palma & 7 & 1 & 0.03 & 0.3 & - & - & - \\
Nuevitas & 7 & 1 & 0.01 & 0.3 & $\mathbf{8 9 3}$ & - & - \\
Contramaestre & 1 & 1 & 0.01 & 0.2 & - & - & - \\
P. Mayari & 3 & 1 & 0.01 & 0.1 & $\mathbf{8 4 6}$ & 0.9 & - \\
U. Oriente & 1 & 0.4 & 0.01 & 0.1 & - & - & - \\
G. Piedra & 2 & 0.4 & 0.01 & 0.2 & - & - & - \\
Guantanamo & 1 & 2 & 0.03 & 0.1 & $\mathbf{6 6 3}$ & 0.7 & - \\
\hline
\end{tabular}

${ }^{*}$ Enrichment factors $>7$ indicate anthropogenic origin.

TABLE 6: Principal components for the air quality monitoring stations of Contramaestre and Guantanamo.

\begin{tabular}{|c|c|c|c|c|c|c|}
\hline \multirow{3}{*}{ Ion } & \multicolumn{6}{|c|}{ Monitoring stations } \\
\hline & \multicolumn{3}{|c|}{ Contramaestre } & \multicolumn{3}{|c|}{ Guantanamo } \\
\hline & 1 & 2 & 3 & 1 & 2 & 3 \\
\hline$\overline{\mathrm{Cl}^{-}}$ & 0.91 & 0.16 & 0.14 & -0.13 & 0.90 & 0.39 \\
\hline $\mathrm{NO}_{3}^{-}$ & 0.02 & -0.11 & 0.91 & 0.92 & -0.09 & -0.11 \\
\hline $\mathrm{SO}_{4}{ }^{2-}$ & 0.25 & 0.33 & 0.86 & 0.96 & -0.05 & -0.16 \\
\hline $\mathrm{CH}_{3} \mathrm{COO}^{-}$ & -0.03 & 0.95 & 0.14 & -0.25 & 0.16 & 0.92 \\
\hline $\mathrm{Na}^{+}$ & 0.92 & 0.15 & 0.01 & -0.08 & 0.95 & 0.18 \\
\hline $\mathrm{NH}_{4}^{+}$ & 0.05 & 0.10 & 0.87 & 0.82 & 0.24 & -0.14 \\
\hline $\mathrm{K}^{+}$ & 0.34 & 0.88 & 0.18 & 0.06 & 0.38 & 0.88 \\
\hline $\mathrm{Mg}^{2+}$ & 0.81 & 0.20 & 0.13 & 0.92 & -0.36 & 0.01 \\
\hline $\mathrm{Ca}^{2+}$ & 0.36 & 0.74 & -0.08 & 0.93 & -0.18 & 0.03 \\
\hline$\%$ variance & 29 & 27 & 27 & 47 & 23 & 21 \\
\hline
\end{tabular}

TABLE 7: Predominant type of synoptic situation (TSS) and number of cold fronts affecting regions of Cuba during the period of November 2008-April 2010.

\begin{tabular}{|c|c|c|c|c|}
\hline Period & $\begin{array}{l}\text { Synoptic } \\
\text { situation }\end{array}$ & Western region & Central region & Eastern region \\
\hline \multirow{2}{*}{$\begin{array}{l}\text { Dry period } \\
\text { November } \\
\text { 2008-April } 2009\end{array}$} & TSS & $\begin{array}{l}\text { Polar continental } \\
\text { anticyclone } \\
\text { (type VIII) }\end{array}$ & $\begin{array}{l}\text { Polar continental } \\
\text { anticyclone } \\
\text { (type VIII) }\end{array}$ & $\begin{array}{l}\text { Polar continental } \\
\text { anticyclone } \\
\text { (type VIII) }\end{array}$ \\
\hline & \# Cold fronts & 17 & 15 & 13 \\
\hline \multirow{2}{*}{$\begin{array}{l}\text { Wet period } \\
\text { May 2009-October } \\
2009\end{array}$} & TSS & $\begin{array}{c}\text { Atlantic anticyclone } \\
\text { (type I) }\end{array}$ & $\begin{array}{c}\text { Atlantic anticyclone } \\
\text { (type I) }\end{array}$ & $\begin{array}{c}\text { Atlantic anticyclone } \\
\text { (type I) }\end{array}$ \\
\hline & \# Cold fronts & 3 & 3 & 3 \\
\hline \multirow{2}{*}{$\begin{array}{l}\text { Dry period } \\
\text { November } \\
\text { 2009-April } 2010\end{array}$} & TSS & $\begin{array}{l}\text { Polar continental } \\
\text { anticyclone } \\
\text { (type VIII) }\end{array}$ & $\begin{array}{l}\text { Polar continental } \\
\text { anticyclone } \\
\text { (type VIII) }\end{array}$ & $\begin{array}{c}\text { Atlantic anticyclone } \\
\text { (type I) }\end{array}$ \\
\hline & \# Cold fronts & 28 & 18 & 11 \\
\hline
\end{tabular}

Seasonal variation of nitrate and sulphate in precipitation is determined by magnitude of and proximity to emission sources and meteorological factors affecting local and regional transport of pollutants.

In order to reduce the risks of air pollution on human health and the environment, it would be desirable to extend the number of monitoring stations and the quantification of their corresponding chemical species. Considering each rain event, it could be possible to refine the allocation of sources in different locations, using for example back-trajectories [17], and specifically contribute to the solution of environmental problems in Cuba.

\section{Conflict of Interests}

The authors declare that there is no conflict of interests regarding the publication of this paper. 


\section{Acknowledgments}

The authors acknowledge Del Carpio Analysis y Asesorías Ltda, Chile, for the use of Ion Chromatograph for ions quantification, Centro Nacional de Medio Ambiente (CENMA) for elements quantification, Instituto de Meteorología de Cuba, Centro de Contaminación y Química Atmosférica, La Habana, for the collection of the samples, and Licentiate in Chemistry Raúl Fuentealba for editorial contribution.

\section{References}

[1] E. Sanhueza, M. Santana, L. Donoso, and M. Pacheco, "Química atmosférica en la Gran Sabana III. Composición iónica y características ácido-básicas de las lluvias," Interciencia, vol. 30, pp. 618-622, 2005.

[2] J. H. Seinfeld and S. N. Pandis, Wet Deposition in Atmospheric Chemistry and Physics from Air Pollution to Climate Change: From Air Pollution to Climate Change, John Wiley \& Sons, Hoboken, NJ, USA, 2nd edition, 2006.

[3] R. D. Vogt, J. Guo, J. Luo et al., "Water chemistry in forested acid sensitive sites in sub-tropical Asia receiving acid rain and alkaline dust," Applied Geochemistry, vol. 22, no. 6, pp. 11401148, 2007.

[4] H. A. Bravo, R. A. Soto, R. E. Sosa et al., "Effect of acid rain on building material of the El Tajín archaeological zone in Veracruz, Mexico," Environmental Pollution, vol. 144, no. 2, pp. 655-660, 2006.

[5] J. Herrera, S. Rodríguez, and A. P. Baéz, "Chemical composition of bulk precipitation in the metropolitan area of Costa Rica, Central America," Atmospheric Research, vol. 94, no. 2, pp. 151160, 2009.

[6] World Meteorological Organization, International Operations Handbook for Measurement of Background Atmospheric Pollution, vol. 491 of WMO, 1978.

[7] World Meteorological Organization, Manual for the GAW Precipitation Chemistry Programme Guidelines, Data Quality Objectives and Standard Operating Procedures, 2004.

[8] D. Migliavacca, E. C. Teixeira, F. Wiegand, A. C. M. Machado, and J. Sanchez, "Atmospheric precipitation and chemical composition of an urban site, Guaíba hydrographic basin, Brazil," Atmospheric Environment, vol. 39, no. 10, pp. 1829-1844, 2005.

[9] J. N. Mphepya, J. J. Pienaar, C. Galy-Lacaux, G. Held, and C. R. Turner, "Precipitation chemistry in semi-arid areas of Southern Africa: a case study of a rural and an industrial site," Journal of Atmospheric Chemistry, vol. 47, no. 1, pp. 1-24, 2004.

[10] U. C. Kulshrestha, A. K. Sarkar, S. S. Srivastava, and D. C. Parashar, "Wet-only and bulk deposition studies at New Delhi (India)," Water, Air, and Soil Pollution, vol. 85, no. 4, pp. 21372142, 1995.

[11] W. C. Keene, A. A. P. Pszenny, J. N. Galloway, and M. E. Hartley, "Sea-salt corrections and interpretation of constituents ratios in marine precipitation," Journal Geophysical Research, vol. 91, pp. 6647-6658, 1986.

[12] R. A. Duce, G. L. Hoffman, and W. H. Zoller, "Atmospheric trace metals at remote northern and southern hemisphere sites. Pollution or natural?” Science, vol. 187, no. 4171, pp. 59-61, 1975.

[13] B. Hernández, "El Niño-Oscilación del Sur (ENOS) y los frentes fríos que arriban a la región occidental cubana," Investigaciones Marinas, vol. 30, no. 2, pp. 3-19, 2002.
[14] T. Jickells, A. Knap, T. Church, J. Galloway, and J. Miller, "Acid rain on Bermuda," Nature, vol. 297, no. 5861, pp. 55-57, 1982.

[15] C. A. Pio, M. L. Salgueiro, and T. V. Nunes, "Seasonal and air mass trajectory: effects on rainwater quality at the southwestern European border," Atmospheric Environment A: General Topics, vol. 25, no. 10, pp. 2259-2266, 1991.

[16] L. B. L. S. Lara, P. Artaxo, L. A. Martinelli et al., "Chemical composition of rainwater and anthropogenic influences in the Piracicaba River Basin, Southeast Brazil," Atmospheric Environment, vol. 35, no. 29, pp. 4937-4945, 2001.

[17] P. T. Nastos, D. Alexakis, H. A. Kanellopoulou, and A. E. Kelepertsis, "Chemical composition of wet deposition in a Mediterranean site Athens, Greece related to the origin of air masses," Journal of Atmospheric Chemistry, vol. 58, no. 2, pp. 167-179, 2007.

[18] C. H. Coelho, J. G. Francisco, R. F. P. Nogueira, and M. L. A. M. Campos, "Dissolved organic carbon in rainwater from areas heavily impacted by sugar cane burning," Atmospheric Environment, vol. 42, no. 30, pp. 7115-7121, 2008.

[19] I. Kita, T. Sato, Y. Kase, and P. Mitropoulos, "Neutral rains at Athens, Greece: a natural safeguard against acidification of rains," Science of the Total Environment, vol. 327, no. 1-3, pp. 285-294, 2004.

[20] X. Hong-wei, X. Hua-yun, L. Ai-min, W. Yan-li, and L. Congqiang, "Chemical composition and source apportionment of rainwater at Guiyang, SW China," Journal of Atmospheric Chemistry, vol. 70, no. 3, pp. 269-228, 2013.

[21] O. A. Al-Khashman, A. Q. Jaradat, and E. Salameh, "Fiveyear monitoring study of chemical characteristics of Wet atmospheric precipitation in the Southern region of Jordan," Environmental Monitoring and Assessment, vol. 185, no. 7, pp. 5715-5727, 2013.

[22] J. N. Galloway, A. H. Knap, and T. M. Church, "The composition of western Atlantic precipitation using shipboard collectors," Journal of Geophysical Research, vol. 88, no. 15, pp. 10859-10864, 1983.

[23] W. H. McDowell, C. Gines Sánchez, C. E. Asbury, and C. R. Ramos Perez, "Influence of sea salt aerosols and long range transport on precipitation chemistry at El Verde, Puerto Rico," Atmospheric Environment A, vol. 24, no. 11, pp. 2813-2821, 1990. 

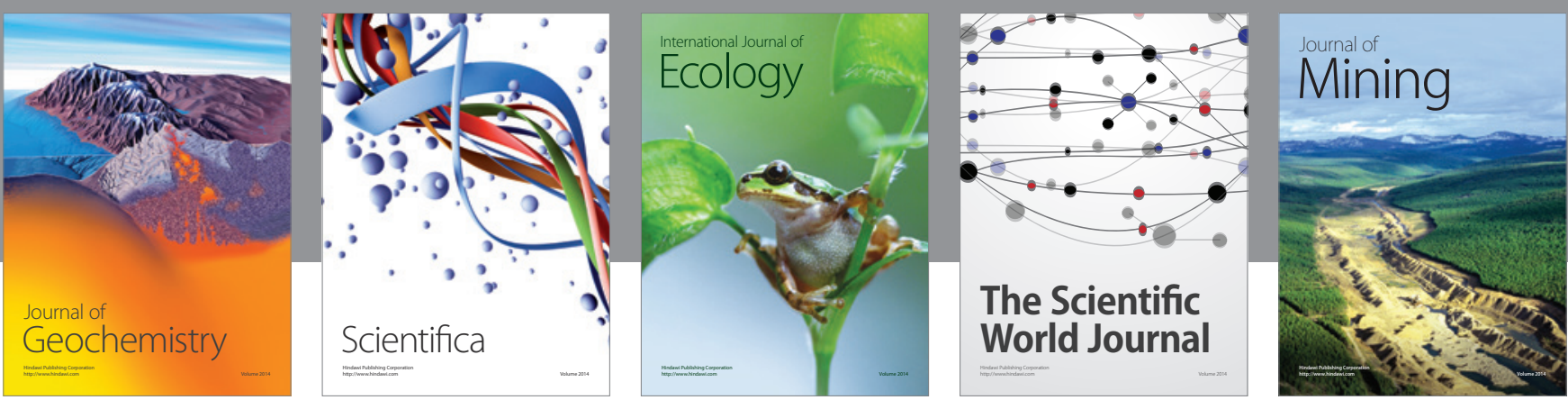

The Scientific World Journal
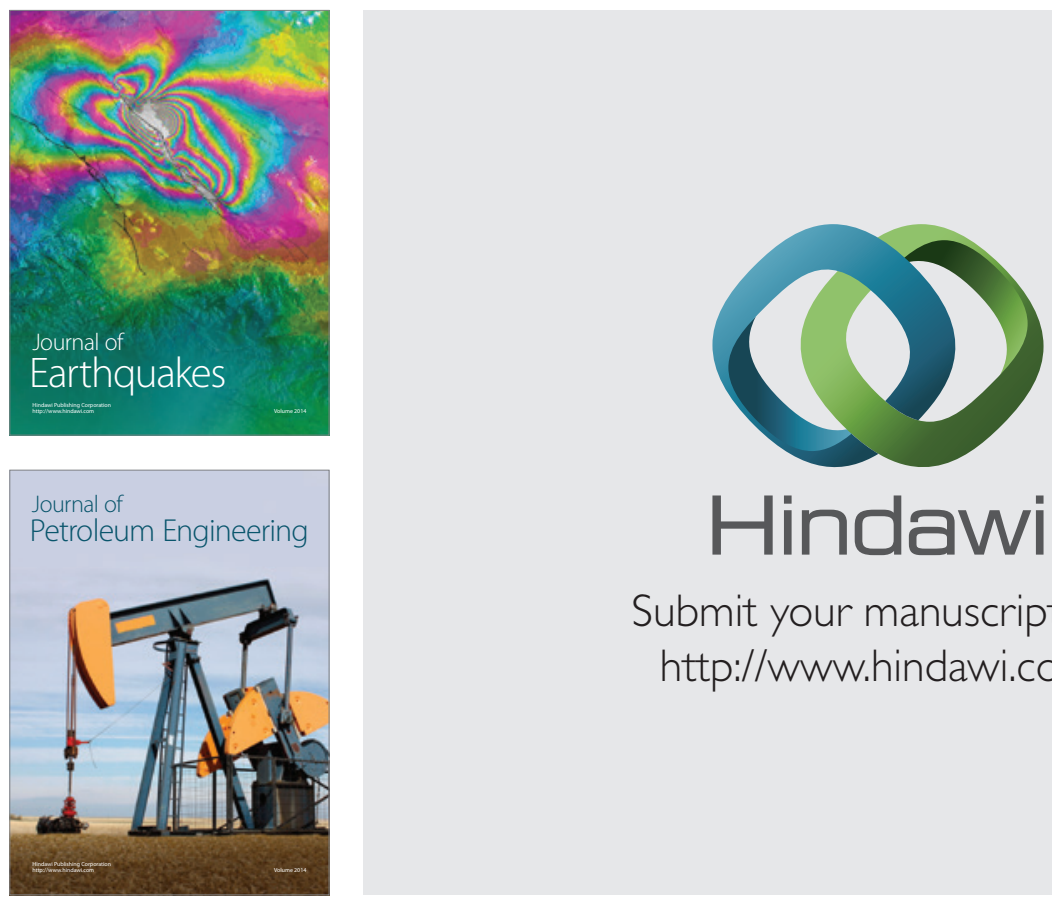

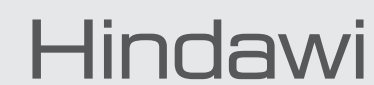

Submit your manuscripts at

http://www.hindawi.com
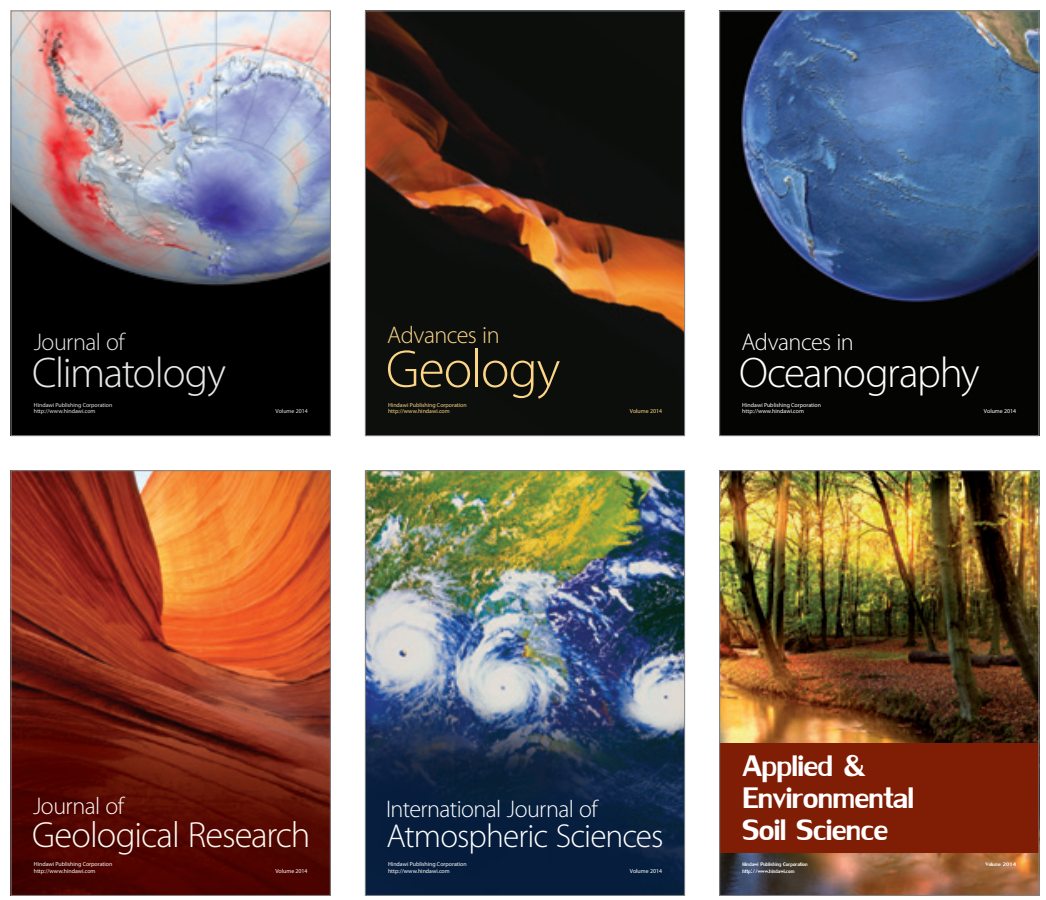
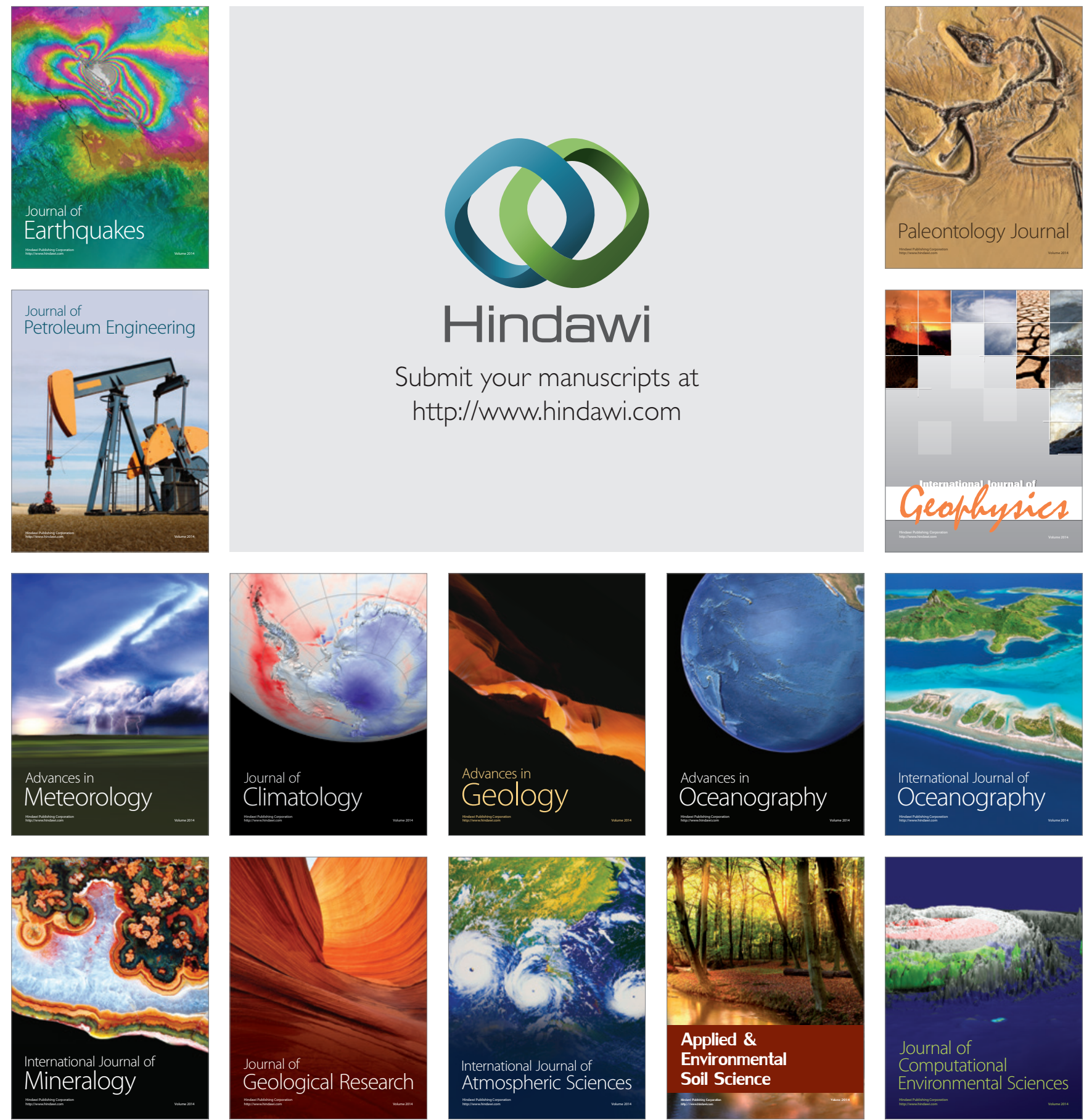